\title{
Immunosuppression by mesenchymal stem cells: mechanisms and clinical applications
}

\author{
Soufiane Ghannamm ${ }^{1,2}$, Carine Bouffi, ${ }^{1,2}$,Farida Djouad ${ }^{1,2}$, Christian Jorgensen ${ }^{1,2,3}$ and Danièle Noë|,2*
}

\begin{abstract}
Mesenchymal stem cells (MSCs) are multipotential nonhematopoietic progenitor cells that are isolated from many adult tissues, in particular from the bone marrow and adipose tissue. Along with their capacity for differentiating into cells of mesodermal lineage, such as adipocytes, osteoblasts and chondrocytes, these cells have also generated great interest for their ability to display immunomodulatory capacities. Indeed, a major breakthrough came with the finding that they are able to induce peripheral tolerance, suggesting they may be used as therapeutic tools in immune-mediated disorders. The present review aims at discussing the current knowledge on the targets and mechanisms of MSC-mediated immunosuppression as well as the potential use of MSCs as modulators of immune responses in a variety of diseases related to alloreactive immunity or autoimmunity.
\end{abstract}

\section{Introduction}

Mesenchymal stem cells (MSCs), also named multipotent mesenchymal stromal cells, are largely studied as new therapeutic tools for a number of clinical applications. Indeed, these cells have been shown to have differentiation capacities as well as paracrine effects via the secretion of growth factors, cytokines, antifibrotic or angiogenic mediators [1]. A large body of studies also indicates that MSCs possess an immunosuppressive function both in vitro and in vivo. We review the present knowledge on the mechanisms underlying the immunomodulatory characteristics of MSCs and their applications in animal models of immune suppression or in clinics.

\footnotetext{
*Correspondence: daniele.noel@inserm.fr

'Inserm U844, CHU Saint Eloi, Bâtiment INM, 80 avenue Augustin Fliche,

Montpellier F-34295, France

Full list of author information is available at the end of the article
}

\section{Definition of mesenchymal stem cells}

MSCs were initially isolated from bone marrow but are now shown to reside in almost every type of connective tissue [2]. MSCs are characterized as a heterogeneous population of cells that proliferate in vitro as plasticadherent cells able to develop as fibroblast colony forming-units [3]. MSCs are distinguished from hematopoietic cells by being negative for the cell surface markers CD11b, CD14, CD34, CD45 and human leukocyte antigen (HLA)-DR but expressing CD73, CD90 and CD105. Importantly, the capacity to differentiate into multiple mesenchymal lineages including bone, fat and cartilage is used as a functional criterion to define MSCs [4].

\section{Immunosuppressive mechanisms of mesenchymal stem cells}

Immunosuppressive function of mesenchymal stem cells requires preliminary activation

MSC-mediated immunosuppression requires preliminary activation of the MSCs by immune cells through the secretion of the proinflammatory cytokine IFN $\gamma$, alone or together with TNF $\alpha$, IL-1 $\alpha$ or IL-1 $\beta[5,6]$. This activation step has also been shown in vivo in a model of graft versus host disease (GVHD) since recipients of IFN $\gamma^{-/-} \mathrm{T}$ cells did not respond to MSC treatment and succumbed to GVHD [7]. Indeed, MSCs from mice deficient for the IFNY receptor 1 do not have immunosuppressive activity, highlighting the important role of IFNY in this process [6].

\section{Mesenchymal stem cell immunosuppression is mediated by soluble factors}

Although target cell-MSC interactions may play a role, the MSC-mediated immunosuppression mainly acts through the secretion of soluble molecules that are induced or upregulated following cross-talk with target cells. Among these factors, indoleamine 2,3-dioxygenase (IDO) has consistently been reported $[8,9]$. On stimulation with IFN $\gamma$, this enzyme metabolizes tryptophan to kynurenin, causing depletion of local tryptophan and accumulation of toxic breakdown products. IDO, however, exerts its effects mainly through the local accumulation of tryptophan metabolites rather than through tryptophan depletion [10]. Whereas the majority of studies 
indicate a potentially important function for IDO, human MSCs lacking both IFNY receptor 1 and IDO still exerted important immunomodulatory activity [11]. This observation may be explained at least in part by a recent study reporting that Toll-like receptors expressed on MSCs augment their immunosuppressive activity in the absence of IFN $\gamma$ through an autocrine IFN $\beta$ signaling loop, which was dependent on protein kinase $\mathrm{R}$ and able to induce IDO [12]. Contrary to human MSCs, lack of IDO activity was constantly reported for murine MSCs $[13,14]$.

Induction of inducible nitric-oxide synthase (iNOS) by murine MSCs and production of nitric oxide was suggested to play a major role in T-cell proliferation inhibition [15]. Nitric oxide is a gaseous bioactive compound affecting macrophage and T-cell functions. iNOS is induced in mouse MSCs after activation by IFN $\gamma$ and TNF $\alpha$, IL- $1 \alpha$ or IL-1 $\beta$, and MSCs from iNOS ${ }^{-/-}$mice had a reduced ability to suppress T-cell proliferation [6] (Bouffi C, Bony C, Courties G, Jorgensen C, Noël D, submitted). The expression level of iNOS mRNA in human MSCs was minimal [14], however, and secretion of nitric oxide by human MSCs was undetectable (Bouffi C, Bony C, Courties G, Jorgensen C, Noël D, unpublished results). Indeed, different mechanisms of immunosuppression exist in different species since human MSCs employ IDO as a major effector molecule whereas nitric oxide plays a critical role in mouse MSCs [14].

Prostaglandin $\mathrm{E}_{2}\left(\mathrm{PGE}_{2}\right)$ has also been involved in the immunosuppressive activity of MSCs. $\mathrm{PGE}_{2}$ is a product of arachidonic acid metabolism that acts as a powerful immune suppressant, inhibiting T-cell mitogenesis and IL-2 production, and is a cofactor for the induction of T-helper (Th) type 2 lymphocyte activity. Production of $\mathrm{PGE}_{2}$ by MSCs is enhanced following TNF $\alpha$ or IFN $\gamma$ stimulation, and its inhibition using specific inhibitors resulted in restoration of T-lymphocyte proliferation [16]. MSC-derived $\mathrm{PGE}_{2}$ was shown to act on macrophages by stimulating the production of IL-10 and on monocytes by blocking their differentiation toward dendritic cells (DCs) $[17,18]$.

Another MSC-secreted factor, IL-6, has been reported to be involved in the inhibition of monocyte differentiation toward DCs, decreasing their stimulation ability on $\mathrm{T}$ cells $[13,19]$. In parallel, the secretion of IL- 6 by MSCs has also been reported to delay apoptosis of lymphocytes and neutrophils [20,21].

Other mediators - such as transforming growth factor beta 1 , hepatocyte growth factor, heme oxygenase 1 and leukemia inhibitory factor - were shown to be produced by MSCs upon activation [16,22-24]. The production of HLA-G5 by MSCs has more recently been shown to suppress T-cell proliferation, as well as natural killer cell cytotoxicity and T-cell cytotoxicity, and to promote the generation of regulatory $\mathrm{T}\left(\mathrm{T}_{\mathrm{REG}}\right)$ cells [25,26]. Cell contact between MSCs and activated $\mathrm{T}$ cells induced IL-10 production, which was essential to stimulate the release of soluble HLA-G5.

Any of these molecules alone does not lead to a complete abrogation of $\mathrm{T}$-cell proliferation, indicating their nonexclusive role. Instead, MSC-mediated immunoregulation is the result of the cumulative action displayed by several molecules.

\section{Suppressive effects on immune cells}

Both $\mathrm{CD}^{+}$and $\mathrm{CD} 8^{+}$T-lymphocyte proliferation stimulated with mitogens or specific antigens is suppressed by MSCs. Suppression occurred with MSCs from autologous or allogeneic sources, indicating that it was not restricted by major histocompatibility complex (MHC) $[27,28]$. Inhibition of proliferation depends on the arrest of $T$ cells in the $G_{0} / G_{1}$ phase of the cell cycle, independently of apoptosis, but instead MSCs promote the survival of stimulated T cells $[29,30]$. MSCs alter other T-cell functions, such as the decrease of production of IFN $\gamma$, IL-2, and TNF $\alpha$ and the increase of IL-4 secretion [16]. MSCs are not targets of $\mathrm{CD}^{+}$cytotoxic T cells but they can suppress the cytotoxic effects of cytotoxic $\mathrm{T}$ cells [31]. Finally, MSCs have been reported to promote, both in vitro and in vivo, the generation of $\mathrm{CD} 4^{+} \mathrm{CD} 25^{+}$or $\mathrm{CD} 8^{+} \mathrm{T}_{\mathrm{REG}}$ cells with functional properties [32]. In vivo data, however, are contradictory [33,34]. Recent studies suggest that MSCs may induce a cytokine profile shift in the Th1/Th2 balance toward the antiinflammatory phenotype Th2 $[35,36]$ (Bouffi C, Bony C, Courties G, Jorgensen C, Noël D, personal communication). Indeed, MSCs can suppress antigen-specific Tcell proliferation and cytotoxicity as well as inducing anti-inflammatory or $\mathrm{T}_{\mathrm{REG}}$ cells.

Most studies have reported that MSCs inhibit the proliferation of $\mathrm{B}$ cells that are activated with antiimmunoglobulin antibodies, soluble CD40 ligand or cytokines [37]. Nevertheless, activated B cells became susceptible to the suppressive activity of MSCs in the presence of exogenously added IFN $\gamma$ [5]. The suppressive effect of IFNY was possibly related to its ability to stimulate the production of IDO by MSCs, which in turn suppressed the proliferative response of effector $\mathrm{T}$ cells. MSCs exert their suppressive effect on B-cell terminal differentiation through the release of humoral factor(s); they also increase B-cell viability while inhibiting proliferation, arresting B lymphocytes in the $G_{0} / G_{1}$ phase of the cell cycle $[38,39]$. Another study, however, reported that MSCs promoted proliferation and differentiation of transitional and naive $\mathrm{B}$ cells into immunoglobulinsecreting cells, and strongly enhanced proliferation and differentiation of memory B-cell populations into plasma cells [40]. Again, differences in cell purification 
procedures, experimental conditions and timing of analysis may explain discrepancies between studies.

Myeloid DCs are the most potent antigen-presenting cells, essential in the induction of immunity and tolerance. During maturation, immature DCs acquire the expression of co-stimulatory molecules and upregulate the expression of MHC class I and class II molecules together with other cell surface markers such as CD11c, CD80, CD83 and CD86. MSCs inhibit in vitro the maturation of monocytes and $\mathrm{CD} 4^{+}$hematopoietic progenitor cells into DCs, as shown by a decreased cellsurface expression of MHC class II and co-stimulatory molecules, as well as a decreased production of IL-12 and TNF $\alpha[16,19,41]$. This effect is at least partially mediated via the secretion of IL- 6 by activated MSCs $[13,19]$ or $\mathrm{PGE}_{2}$, which was directly responsible for blocking DC maturation [18]. These studies suggest that MSCs might direct DC maturation toward an anti-inflammatory or regulatory phenotype responsible for an attenuated T-cell response.

Natural killer cells exhibit cytolytic activity that mainly targets cells which lack expression of HLA class I molecules. Killing by natural killer cells is regulated by a balance of signals transmitted by activating and inhibitory receptors interacting with HLA molecules on target cells. MSCs have been shown to suppress IL-2-driven or IL-15-driven natural killer cell proliferation, IFNY production and cytotoxicity against HLA class I-expressing targets [42]. Some of these effects seem to depend on cell-to-cell contact and on the release of soluble factors, including transforming growth factor beta 1 and $\mathrm{PGE}_{2}$, suggesting the existence of diverse mechanisms for MSCmediated natural killer cell suppression.

Neutrophils are also important mediators of innate immunity responsible for microorganism killing via the production of reactive oxygen species. MSCs were shown to delay apoptosis of neutrophils through an IL-6mediated mechanism that was associated with the downregulation of reactive oxygen species [20]. Delayed apoptosis was thought to preserve the pool of neutrophils that will be rapidly available in response to infections. Recently, Nemeth and colleagues suggested that LPS and TNFa stimulated MSCs during sepsis to secrete high levels of $\mathrm{PGE}_{2}$, which in turn reprogrammed monocytes and macrophages to produce large amounts of IL-10. The released IL-10 seemed to prevent neutrophils from migrating into tissues and causing oxidative damage, thus mitigating multiorgan damage [17]. The results therefore suggest that MSCs may modulate the host innate response and improve survival by preventing sepsis.

The various studies indicate that MSCs suppress the function of several immune cells; notably the proliferation of $\mathrm{T}$ lymphocytes, the $\mathrm{DC}$ maturation and the induction of anti-inflammatory or $\mathrm{T}_{\mathrm{REG}}$ cells. Some

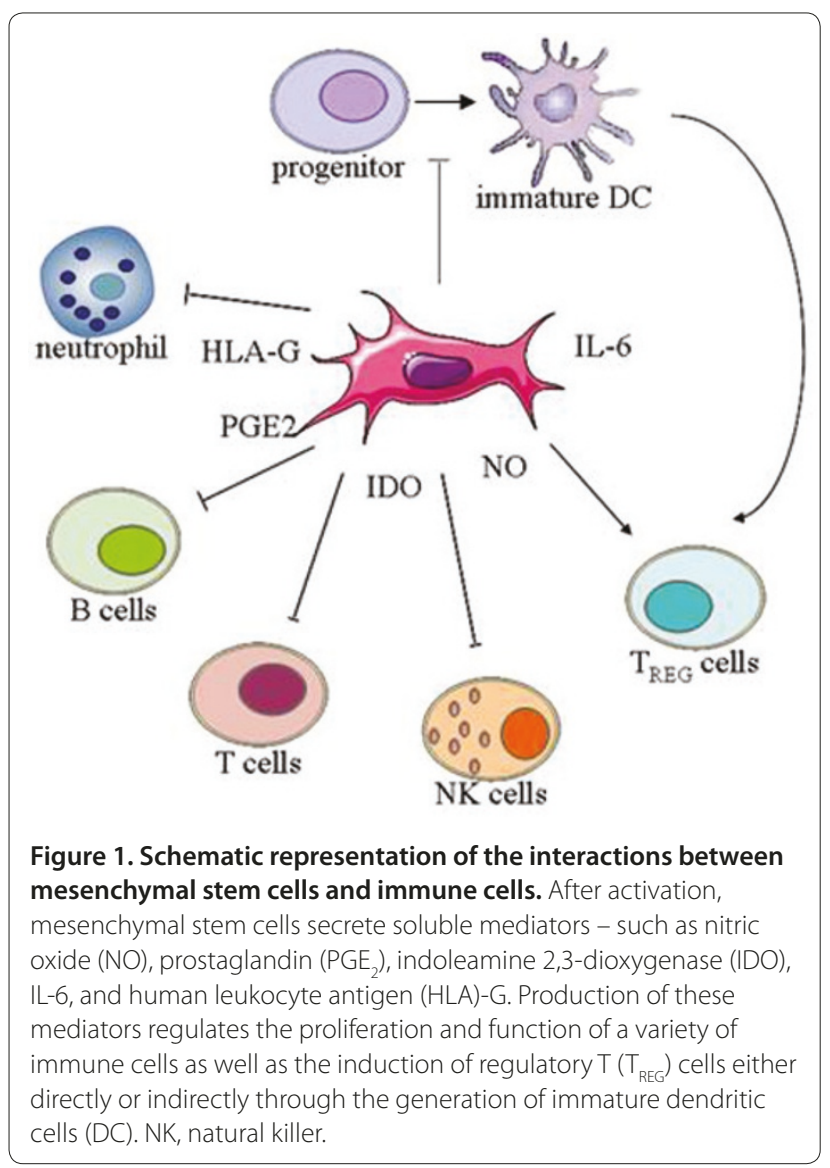

mechanisms of immunomodulation have been reproduced by several groups, in particular the secretion of IDO, PGE ${ }_{2}$, nitric oxide and HLA-G5 (Figure 1). Differences in the secretome profile - particularly for IDO and nitric oxide - exist between humans and mice, however, suggesting that several mechanisms are likely to be responsible for the various effects reported to date. Our recent data suggest that MSCs exert two levels of action (Bouffi C, Bony C, Courties G, Jorgensen C, Noël $\mathrm{D}$, personal communication). One level occurs locally via the secretion of mediators that inhibit the proliferation of immune cells at the vicinity of MSCs. The second induces a systemic response, either an anti-inflammatory Th2 immune profile or, in some instances, the generation of $\mathrm{T}_{\mathrm{REG}}$ cells.

\section{Homing capacities}

The trafficking and homing properties of MSCs are of particular interest for clinical applications aiming at using non-invasive systemic cell administration to treat inflammation. MSCs have been shown to express a variety of chemokines and chemokine receptors and can home to sites of inflammation by migrating towards inflammatory chemokines and cytokines $[43,44]$. Depending on 
the studies, heterogeneity in surface receptor expression is observed - which is probably due to differences in culture conditions and limitations in detection techniques. Homing of cultured MSCs, however, is inefficient compared with leukocytes. This inefficiency has been attributed to a lack of cell adhesion and chemokine receptors but also to the size of MSCs that promote passive cell entrapment and reduce trafficking [45]. Together with the evidence that host MSCs can mobilize in response to inflammation or injury, systemically infused MSCs are also frequently observed within the bone marrow or in injured tissues. Indeed, although the understanding of the underlying mechanisms is still required, accumulating evidence suggests that systemic infusion of MSCs may be used for immunosuppressive treatments of various disorders.

\section{Therapeutic applications of mesenchymal stem cells}

The hypoimmunogenicity of MSCs supports their therapeutic interest in a variety of diseases related to alloreactive immunity or autoimmunity. Indeed, the poor immunogenicity of these cells demonstrated in vitro and in vivo favors the possible use of allogeneic MSCs in acute clinical conditions where the availability of sufficient numbers of cells is rapidly needed. The use of autologous cells, however, may have therapeutic applications in autoimmune diseases or pathologies that allow enough time for isolation and in vitro expansion of MSCs. The few clinical applications performed to date confirm safety with a lack of major adverse side effects. Indeed, serial magnetic resonance imaging performed in 226 patients who received MSCs for various orthopedic conditions showed no evidence of malignant transformation for a mean follow-up of $10.6 \pm 7.3$ months [46]. Accordingly, although some studies described the capacity of human MSCs to accumulate chromosomal instability in vitro, it was recently reported that, even though some aneuploidy was detected, MSCs showed progressive growth arrest and entered senescence without evidence of transformation either in vitro or in vivo [47]. Further studies are needed, however, to address the in vivo survival of MSCs, ectopic tissue formation and malignant transformation on a larger number of cell preparations.

\section{Transplantation}

One of the first in vivo studies showed that systemic infusion of MSCs isolated from bone marrow prolonged the survival of allogeneic skin grafts from 7 to 11 days in baboons receiving MSCs [48]. Using a semi-allogeneic heart transplant mouse model, infusion of donorderived MSCs prolonged cardiac allograft survival through tolerance induction, which was due to CD $4^{+} \mathrm{CD} 25^{+}$Foxp $^{+} \mathrm{T}_{\mathrm{REG}}$ cell expansion and impaired anti-donor Th1 activity [49].
In hematopoietic stem cell (HSC) transplantation, MSCs may help reconstitution of the bone marrow stroma after chemoradiotherapy and enhance HSC engraftment. As early as 2000, autologous MSC infusion was shown to improve the outcome of HSC transplantation in advanced breast cancer patients [50]. Infusion of allogeneic MSCs, contrary to syngeneic MSCs, has since been demonstrated to result in rejection of stem cell grafts in a murine model of allogeneic bone marrow transplantation [51]. The results in animal models on the potential use of MSCs to prevent rejection of allogeneic grafts are conflicting (for a review, see [52]). In a more recent study, however, co-transplantation of donor MSCs with HLA-disparate CD $34^{+}$HSCs resulted in sustained hematopoietic engraftment in 14 children without any adverse reaction, indicating that MSCs reduce the risk of graft failure in haplo-identical HSC transplant recipients [53].

MSC infusion may also be very helpful in cord blood transplantation where the limited dose of stem cells delays engraftment and favors graft failure. This cell therapy approach has also been used as GVHD prophylaxis in HSC transplantation.

\section{Graft versus host disease}

The most significant results on the immunosuppressive effects of MSCs so far have been observed in the treatment of acute GVHD after allogeneic stem cell transplantation. GVHD occurring beyond 100 days after HSC transplantation is generally called chronic GVHD, which has to be distinguished from acute GVHD that includes persistent, recurrent, or late-onset acute GVHD.

The first case of ex vivo expanded haplo-identical MSC injection in a patient with severe grade IV GVHD of the gut and liver resulted in a striking improvement of the disease [54]. A phase II study has since reported that 30 out of 55 patients had a complete response and nine patients showed improvement, indicating that, irrespective of the donor, MSC infusion might be an effective therapy for patients with steroid-resistant, acute GVHD [55]. Another report on patients with leukemia, however, showed effective prevention of acute GVHD but a higher incidence of relapses in patients who were co-transplanted with MSCs and MHC-identical allogeneic HSCs [56]. Co-transplantation of third-party donor HSCs with cord blood transplants has been shown to overcome the limitation posed by low cellularity of cord blood units for unrelated transplants in adults. For optimization of this therapeutic approach, the risk of GVHD still has to be reduced. The co-infusion of MSCs from the same HSC donors was therapeutically effective for severe acute GVHD but no significant differences in cord blood engraftment and incidence of GVHD were observed [57]. The results indicate the therapeutic potential of MSCs for 
acute GVHD control, but underline the need for better control of safety issues.

\section{Autoimmune diseases}

Based on their ability to moderate T-cell proliferation and function, MSCs have also been proposed as a therapeutic option in the treatment of autoimmune diseases. They have therefore been tested in a variety of animal models of diabetes, experimental autoimmune encephalomyelitis, systemic lupus erythematosus or rheumatoid arthritis.

Contrasted results were reported in rheumatoid arthritis using the experimental collagen-induced arthritis model. We first showed that injection of the allogeneic C3H10T1/2 MSC line did not reverse the disease score [58]. In the same model, however, a single injection of primary MSCs was shown to prevent the occurrence of severe arthritis, which was associated with a decrease in serum proinflammatory cytokines [59,60]. The use of human adipose-derived MSCs was effective in the xenogeneic collagen-induced arthritis model. The therapeutic efficacy was associated with decreased antigen-specific Th1/Th17 cell expansion, enhanced secretion of IL-10 and generation of $\mathrm{CD} 44^{+} \mathrm{CD} 25^{+} \mathrm{FoxP}^{+} \mathrm{T}_{\mathrm{REG}}$ cells with the capacity to suppress self-reactive T-effector responses [61]. Another study reported no convincing increase of $\mathrm{T}_{\mathrm{REG}}$ cells in vivo despite in vitro evidence of $\mathrm{T}$-cell inhibition by MSCs [62]. Our recent data with primary syngeneic and allogeneic MSCs indicate that MSCs may have a dual effect: locally, reducing the clinical signs of inflammation in the joints, probably via the secretion of antiproliferative mediators; and systemically, by switching the polarization of the host response towards a Th2 immune profile (Bouffi C, Bony C, Courties G, Jorgensen C, Noël D, personal communication). The divergent mechanistic results obtained from the various studies underline the complexity of the MSC-mediated immunosuppressive process and the differences that may be attributed to the various MSC species used [14] and to the different techniques of MSC isolation and culture $[7,59]$.

In the experimental autoimmune encephalomyelitis murine model of multiple sclerosis, MSCs were shown to decrease the clinical signs associated with demyelinization when injected before or at the onset of the disease, demonstrating the therapeutic efficacy of MSCs [34]. This effect was associated with immune suppression of effector T cells leading to IL-2 reversible T-cell anergy. Subsequently, it was reported that MSCs inhibited T-cell activation with reduced IL-17 and TNFa levels via the secretion of CCL2 by MSCs [63].

MSC transplantation conferred significant therapeutic effects in the systemic lupus erythematosus mouse model of lupus by reconstructing the osteoblastic niche and restoring immune homeostasis [64]. On the basis of these promising results, four treatment-refractory patients were treated with allogeneic MSCs. The patients presented a stable 12-month to 18-month disease remission, showing improvement in serologic markers and renal function [64]. Their data showed that MSC infusion restored the Foxp $3^{+}$cell levels in both mice and systemic lupus erythematosus patients.

Development of autoimmune diabetes results from immune cell dysfunction to maintain peripheral and central tolerance. MSCs may therefore be helpful in regulating $\mathrm{T}_{\mathrm{REG}}$ /autoreactive $\mathrm{T}$-cell balance. The first results were obtained in the NOD/SCID model of chemically induced diabetes using human MSCs. In the treated diabetic mice, an increase in pancreatic islets and beta cells producing insulin was detected with a few glomerular endothelial cells of human origin. There was also a decrease in macrophage infiltration, resulting in the prevention of pancreatic injury [65]. The role of MSCs was first suggested to induce the regeneration of endogenous insulin-secreting cells, and, second, to inhibit the T-cell-mediated immune responses against newly formed beta cells [66]. A shift of the host immune response toward Th2-like responses was proposed to occur in treated NOD mice [67].

\section{Conclusion}

Overall, the current data indicate that MSCs represent a promising alternative strategy in the treatment of various immune-mediated diseases. Encouraging results have already been obtained from the clinics. Many questions remain to be addressed, however, in order to provide better ways to control and optimize the immune response for the benefit of the patient. This implies a better understanding of the underlying mechanisms of immunosuppression as well as satisfying safety concerns as regards the in vivo survival, formation of ectopic tissue and malignant transformation.

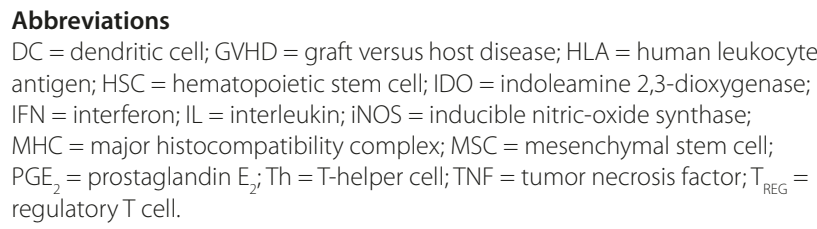
antigen; HSC = hematopoietic stem cell; IDO = indoleamine 2,3-dioxygenase; IFN = interferon; IL = interleukin; iNOS = inducible nitric-oxide synthase; $\mathrm{MHC}=$ major histocompatibility complex; $\mathrm{MSC}=$ mesenchymal stem cell; $\mathrm{PGE}_{2}=$ prostaglandin $\mathrm{E}_{2} ; \mathrm{Th}=\mathrm{T}$-helper cell; $\mathrm{TNF}=$ tumor necrosis factor; $\mathrm{T}_{\mathrm{REG}}=$ regulatory $\top$ cell.

\section{Competing interests}

The authors declare that they have no competing interests.

\section{Acknowledgements}

Work in the Inserm U844 laboratory is supported by the Inserm Institute, the University of Montpellier I and grants from the Agence Nationale de la Recherche (project ANR Physio 2006 Immunostem).

\section{Author details}

'Inserm, U844, Montpellier F-34091, France. Université Montpellier 1, UFR de Médecine, Montpellier F-34000, France. ${ }^{3}$ Service d'immuno-Rhumatologie, Hôpital Lapeyronie, Montpellier F-34295, France

Published: 15 March 2010 


\section{References}

1. Djouad F, Bouffi C, Ghannam S, Noel D, Jorgensen C: Mesenchymal stem cells: innovative therapeutic tools for rheumatic diseases. Nat Rev Rheumatol 2009, 5:392-399.

2. da Silva Meirelles L, Chagastelles PC, Nardi NB: Mesenchymal stem cells reside in virtually all post-natal organs and tissues. J Cell Sci 2006, 119:2204-2213.

3. Pittenger MF, Mackay AM, Beck SC, Jaiswal RK, Douglas R, Mosca JD, Moorman MA, Simonetti DW, Craig S, Marshak DR: Multilineage potential of adult human mesenchymal stem cells. Science 1999, 284:143-147.

4. Dominici M, Le Blanc K, Mueller I, Slaper-Cortenbach I, Marini F, Krause D, Deans R, Keating A, Prockop D, Horwitz E: Minimal criteria for defining multipotent mesenchymal stromal cells. The International Society for Cellular Therapy position statement. Cytotherapy 2006, 8:315-317.

5. Krampera M, Cosmi L, Angeli R, Pasini A, Liotta F, Andreini A, Santarlasci V, Mazzinghi B, Pizzolo G, Vinante F, Romagnani P, Maggi E, Romagnani S, Annunziato F: Role for interferon-gamma in the immunomodulatory activity of human bone marrow mesenchymal stem cells. Stem Cells 2006, 24:386-398

6. Ren G, Zhang L, Zhao X, Xu G, Zhang Y, Roberts Al, Zhao RC, Shi Y: Mesenchymal stem cell-mediated immunosuppression occurs via concerted action of chemokines and nitric oxide. Cell Stem Cell 2008 , 2:141-150.

7. Polchert D, Sobinsky J, Douglas G, Kidd M, Moadsiri A, Reina E, Genrich K, Mehrotra S, Setty S, Smith B, Bartholomew A: IFN-gamma activation of mesenchymal stem cells for treatment and prevention of graft versus host disease. Eur J Immuno/ 2008, 38:1745-1755.

8. Meisel R, Zibert A, Laryea M, Gobel U, Daubener W, Dilloo D: Human bone marrow stromal cells inhibit allogeneic T-cell responses by indoleamine 2,3-dioxygenase-mediated tryptophan degradation. Blood 2004, 103:4619-4621.

9. Maby-El Hajjami H, Ame-Thomas P, Pangault C, Tribut O, DeVos J, Jean R, Bescher N, Monvoisin C, Dulong J, Lamy T, Fest T, Tarte K: Functional alteration of the lymphoma stromal cell niche by the cytokine context: role of indoleamine-2,3 dioxygenase. Cancer Res 2009, 69:3228-3237.

10. Ryan JM, Barry F, Murphy JM, Mahon BP: Interferon-gamma does not break, but promotes the immunosuppressive capacity of adult human mesenchymal stem cells. Clin Exp Immunol 2007, 149:353-363.

11. Gieseke F, Schutt B, Viebahn S, Koscielniak E, Friedrich W, Handgretinger R, Muller I: Human multipotent mesenchymal stromal cells inhibit proliferation of PBMCs independently of IFNpR1 signaling and IDO expression. Blood 2007, 110:2197-2200.

12. Opitz CA, Litzenburger UM, Lutz C, Lanz TV, Tritschler I, Koppel A, Tolosa E, Hoberg M, Anderl J, Aicher WK, Weller M, Wick W, Platten M: Toll-like receptor engagement enhances the immunosuppressive properties of human bone marrow-derived mesenchymal stem cells by inducing indoleamine2,3-dioxygenase-1 via interferon-beta and protein kinase R. Stem Cells 2009, 27:909-919.

13. Djouad F, Charbonnier LM, Bouffi C, Louis-Plence P, Bony C, Apparailly F, Cantos C, Jorgensen C, Noel D: Mesenchymal stem cells inhibit the differentiation of dendritic cells through an interleukin-6-dependent mechanism. Stem Cells 2007, 25:2025-2032.

14. Ren G, Su J, Zhang L, Zhao X, Ling W, L'Huillie A, Zhang J, Lu Y, Roberts Al, Ji W, Zhang $H$, Rabson AB, Shi Y: Species variation in the mechanisms of mesenchymal stem cell-mediated immunosuppression. Stem Cells 2009, 27:1954-1962

15. Sato K, Ozaki K, Oh I, Meguro A, Hatanaka K, Nagai T, Muroi K, Ozawa K: Nitric oxide plays a critical role in suppression of T-cell proliferation by mesenchymal stem cells. Blood 2007, 109:228-234.

16. Aggarwal S, Pittenger MF: Human mesenchymal stem cells modulate allogeneic immune cell responses. Blood 2005, 105:1815-1822.

17. Nemeth K, Leelahavanichkul A, Yuen PS, Mayer B, Parmelee A, Doi K, Robey PG, Leelahavanichkul K, Koller BH, Brown JM, Hu X, Jelinek I, Star RA, Mezey E: Bone marrow stromal cells attenuate sepsis via prostaglandin $E_{2}$ dependent reprogramming of host macrophages to increase their interleukin-10 production. Nat Med 2009, 15:42-49.

18. Spaggiari GM, Abdelrazik H, Becchetti F, Moretta L: MSCs inhibit monocytederived DC maturation and function by selectively interfering with the generation of immature DCs: central role of MSC-derived prostaglandin $\mathrm{E}_{2}$. Blood 2009, 113:6576-6583.

19. Jiang XX, Zhang Y, Liu B, Zhang SX, Wu Y, Yu XD, Mao N: Human mesenchymal stem cells inhibit differentiation and function of monocytederived dendritic cells. Blood 2005, 105:4120-4126.

20. Raffaghello L, Bianchi G, Bertolotto M, Montecucco F, Busca A, Dallegri F, Ottonello L, Pistoia V: Human mesenchymal stem cells inhibit neutrophil apoptosis: a model for neutrophil preservation in the bone marrow niche. Stem Cells 2008, 26:151-162

21. Xu G, Zhang Y, Zhang L, Ren G, Shi Y: The role of IL-6 in inhibition of lymphocyte apoptosis by mesenchymal stem cells. Biochem Biophys Res Commun 2007, 361:745-750

22. Di Nicola M, Carlo-Stella C, Magni M, Milanesi M, Longoni PD, Matteucci P, Grisanti S, Gianni AM: Human bone marrow stromal cells suppress T-lymphocyte proliferation induced by cellular or nonspecific mitogenic stimuli. Blood 2002, 99:3838-3843.

23. Chabannes D, Hill M, Merieau E, Rossignol J, Brion R, Soulillou JP, Anegon I, Cuturi MC: A role for heme oxygenase- 1 in the immunosuppressive effect of adult rat and human mesenchymal stem cells. Blood 2007, 110:3691-3694.

24. Nasef A, Mazurier C, Bouchet S, Francois S, Chapel A, Thierry D, Gorin NC, Fouillard L: Leukemia inhibitory factor: role in human mesenchymal stem cells mediated immunosuppression. Cell Immunol 2008, 253:16-22.

25. Selmani Z, Naji A, Zidi I, Favier B, Gaiffe E, Obert L, Borg C, Saas P, Tiberghien P, Rouas-Freiss N, Carosella ED, Deschaseaux F: Human leukocyte antigen-G5 secretion by human mesenchymal stem cells is required to suppress T lymphocyte and natural killer function and to induce $\mathrm{CD}^{+}{ }^{+} \mathrm{CD} 25^{\text {high }} \mathrm{FOXP3}{ }^{+}$regulatory T cells. Stem Cells 2008, 26:212-222.

26. Nasef A, Zhang YZ, Mazurier C, Bouchet S, Bensidhoum M, Francois S, Gorin NC, Lopez M, Thierry D, Fouillard L, Chapel A: Selected Stro-1-enriched bone marrow stromal cells display a major suppressive effect on lymphocyte proliferation. Int J Lab Hematol 2009, 31:9-19.

27. Djouad F, Plence P, Bony C, Tropel P, Apparailly F, Sany J, Noel D, Jorgensen C: Immunosuppressive effect of mesenchymal stem cells favors tumor growth in allogeneic animals. Blood 2003, 102:3837-3844.

28. Le Blanc K, Tammik L, Sundberg B, Haynesworth SE, Ringden O: Mesenchymal stem cells inhibit and stimulate mixed lymphocyte cultures and mitogenic responses independently of the major histocompatibility complex. Scand J Immunol 2003, 57:11-20.

29. Glennie S, Soeiro I, Dyson PJ, Lam EW, Dazzi F: Bone marrow mesenchymal stem cells induce division arrest anergy of activated T cells. Blood 2005, 105:2821-2827.

30. Benvenuto F, Ferrari S, Gerdoni E, Gualandi F, Frassoni F, Pistoia V, Mancardi G, Uccelli A: Human mesenchymal stem cells promote survival of T cells in a quiescent state. Stem Cells 2007, 25:1753-1760.

31. Rasmusson I, Ringden O, Sundberg B, Le Blanc K: Mesenchymal stem cells inhibit the formation of cytotoxic T lymphocytes, but not activated cytotoxic T lymphocytes or natural killer cells. Transplantation 2003, 76:1208-1213.

32. Prevosto C, Zancolli M, Canevali P, Zocchi MR, Poggi A: Generation of CD4 ${ }^{+}$or $\mathrm{CD}^{+}$regulatory $T$ cells upon mesenchymal stem cell-lymphocyte interaction. Haematologica 2007, 92:881-888.

33. Parekkadan B, Tilles AW, Yarmush ML: Bone marrow-derived mesenchymal stem cells ameliorate autoimmune enteropathy independently of regulatory T cells. Stem Cells 2008, 26:1913-1919.

34. Zappia E, Casazza S, Pedemonte E, Benvenuto F, Bonanni I, Gerdoni E, Giunti D, Ceravolo A, Cazzanti F, Frassoni F, Mancardi G, Uccelli A: Mesenchyma stem cells ameliorate experimental autoimmune encephalomyelitis inducing T-cell anergy. Blood 2005, 106:1755-1761.

35. Zhou H, Jin Z, Liu J, Yu S, Cui Q, Yi D: Mesenchymal stem cells might be used to induce tolerance in heart transplantation. Med Hypotheses 2008, 70:785-787.

36. Haniffa MA, Wang XN, Holtick U, Rae M, Isaacs JD, Dickinson AM, Hilkens CM, Collin MP: Adult human fibroblasts are potent immunoregulatory cells and functionally equivalent to mesenchymal stem cells. J Immuno/ 2007, 179:1595-1604.

37. Corcione A, Benvenuto F, Ferretti E, Giunti D, Cappiello V, Cazzanti F, Risso M, Gualandi F, Mancardi GL, Pistoia V, Uccelli A: Human mesenchymal stem cells modulate B-cell functions. Blood 2006, 107:367-372.

38. Tabera S, Perez-Simon JA, Diez-Campelo M, Sanchez-Abarca LI, Blanco B, Lopez A, Benito A, Ocio E, Sanchez-Guijo FM, Canizo C, San Miquel JF: The effect of mesenchymal stem cells on the viability, proliferation and differentiation of B-lymphocytes. Haematologica 2008, 93:1301-1309.

39. Asari S, Itakura S, Ferreri K, Liu CP, Kuroda Y, Kandeel F, Mullen Y: Mesenchymal stem cells suppress B-cell terminal differentiation. Exp Hemato/ 2009, 37:604-615. 
40. Traggiai E, Volpi S, Schena F, Gattorno M, Ferlito F, Moretta L, Martini A: Bone marrow-derived mesenchymal stem cells induce both polyclonal expansion and differentiation of $B$ cells isolated from healthy donors and systemic lupus erythematosus patients. Stem Cells 2008, 26:562-569.

41. Nauta AJ, Kruisselbrink AB, Lurvink E, Willemze R, Fibbe WE: Mesenchymal stem cells inhibit generation and function of both $\mathrm{CD} 34^{+}$-derived and monocyte-derived dendritic cells. J Immunol 2006, 177:2080-2087.

42. Sotiropoulou PA, Perez SA, Gritzapis AD, Baxevanis CN, Papamichail M: Interactions between human mesenchymal stem cells and natural killer cells. Stem Cells 2006, 24:74-85.

43. Honczarenko M, Le Y, Swierkowski M, Ghiran I, Glodek A, Silberstein LE: Human bone marrow stromal cells express a distinct set of biologically functional chemokine receptors. Stem Cells 2005, 24:1030-1041.

44. Sordi V, Malosio ML, Marchesi F, Mercalli A, Melzi R, Giordano T, Belmonte N, Ferrari G, Leone BE, Bertuzzi F, Zerbini G, Allavena P, Bonifacio E, Piemonti L: Bone marrow mesenchymal stem cells express a restricted set of functionally active chemokine receptors capable of promoting migration to pancreatic islets. Blood 2005, 106:419-427.

45. Karp JM, Leng Teo GS: Mesenchymal stem cell homing: the devil is in the details. Cell Stem Cell 2009, 4:206-216.

46. Centeno CJ, Schultz JR, Cheever M, Robinson B, Freeman M, Marasco W: Safety and complications reporting on the re-implantation of cultureexpanded mesenchymal stem cells using autologous platelet lysate technique. Curr Stem Cell Res Ther 2009, Dec 2, Epub ahead of print

47. Tarte K, Gaillard J, Lataillade JJ, Fouillard L, Becker M, Mossafa H, Tchirkov A Rouard H, Henry C, Splingard M, Dulong J, Monnier D, Gourmelon P, Gorin NC, Sensebe $L:$ Clinical-grade production of human mesenchymal stromal cells: occurrence of aneuploidy without transformation. Blood 2009, Dec 23, Epub ahead of print

48. Bartholomew A, Patil S, Mackay A, Nelson M, Buyaner D, Hardy W, Mosca J, Sturgeon C, Siatskas M, Mahmud N, Ferrer K, Deans R, Moseley A, Hoffman R, Devine SM: Baboon mesenchymal stem cells can be genetically modified to secrete human erythropoietin in vivo. Hum Gene Ther 2001, 12:1527-1541.

49. Casiraghi F, Azzollini N, Cassis P, Imberti B, Morigi M, Cugini D, Cavinato RA, Todeschini M, Solini S, Sonzogni A, Perico N, Remuzzi G, Noris M: Pretransplant infusion of mesenchymal stem cells prolongs the survival of a semiallogeneic heart transplant through the generation of regulatory T cells. J Immuno/ 2008, 181:3933-3946.

50. Koc ON, Gerson SL, Cooper BW, Dyhouse SM, Haynesworth SE, Caplan Al, Lazarus HM: Rapid hematopoietic recovery after coinfusion of autologousblood stem cells and culture-expanded marrow mesenchymal stem cells in advanced breast cancer patients receiving high-dose chemotherapy. J Clin Oncol 2000, 18:307-316.

51. Nauta AJ, Westerhuis G, Kruisselbrink AB, Lurvink EG, Willemze R, Fibbe WE: Donor-derived mesenchymal stem cells are immunogenic in an allogeneic host and stimulate donor graft rejection in a nonmyeloablative setting. Blood 2006, 108:2114-2120

52. Le Blanc K, Ringden O: Immunobiology of human mesenchymal stem cells and future use in hematopoietic stem cell transplantation. Biol Blood Marrow Transplant 2005, 11:321-334

53. Ball LM, Bernardo ME, Roelofs H, Lankester A, Cometa A, Egeler RM, Locatelli F, Fibbe WE: Cotransplantation of ex vivo expanded mesenchymal stem cells accelerates lymphocyte recovery and may reduce the risk of graft failure in haploidentical hematopoietic stem-cell transplantation. Blood 2007, 110:2764-2767.

54. Le Blanc K, Rasmusson I, Sundberg B, Gotherstrom C, Hassan M, Uzunel M, Ringden O: Treatment of severe acute graft-versus-host disease with third party haploidentical mesenchymal stem cells. Lancet 2004, 363:1439-1441.
55. Le Blanc K, Frassoni F, Ball L, Locatelli F, Roelofs H, Lewis I, Lanino E, Sundberg B, Bernardo ME, Remberger M, Dini G, Egeler RM, Bacigalupo A, Fibbe W, Ringden $\mathrm{O}$ : Mesenchymal stem cells for treatment of steroid-resistant, severe, acute graft-versus-host disease: a phase II study. Lancet 2008, 371:1579-1586.

56. Ning H, Yang F, Jiang M, Hu L, Feng K, Zhang J, Yu Z, Li B, Xu C, Li Y, Wang J, Hu J, Lou $X$, Chen $\mathrm{H}$ : The correlation between cotransplantation of mesenchymal stem cells and higher recurrence rate in hematologic malignancy patients: outcome of a pilot clinical study. Leukemia 2008, 22:593-599.

57. Gonzalo-Daganzo R, Regidor C, Martin-Donaire T, Rico MA, Bautista G, Krsnik I, Fores R, Ojeda E, Sanjuan I, Garcia-Marco JA, Navarro B, Gil S, Sanchez R, Panadero N, Gutierrez Y, Garcia-Berciano M, Perez N, Millan I, Cabrera R, Fernandez MN: Results of a pilot study on the use of third-party donor mesenchymal stromal cells in cord blood transplantation in adults. Cytotherapy 2009, 11:278-288.

58. Djouad F, Fritz V, Apparailly F, Louis-Plence P, Bony C, Sany J, Jorgensen C, Noel D: Reversal of the immunosuppressive properties of mesenchymal stem cells by tumor necrosis factor alpha in collagen-induced arthritis. Arthritis Rheum 2005, 52:1595-1603.

59. Augello A, Tasso R, Negrini SM, Cancedda R, Pennesi G: Cell therapy using allogeneic bone marrow mesenchymal stem cells prevents tissue damage in collagen-induced arthritis. Arthritis Rheum 2007, 56:1175-1186.

60. Mao F, Xu WR, Qian H, Zhu W, Yan YM, Shao QX, Xu HX: Immunosuppressive effects of mesenchymal stem cells in collagen-induced mouse arthritis. Inflamm Res 2009, 59:219-225.

61. Gonzalez MA, Gonzalez-Rey E, Rico L, Buscher D, Delgado M: Treatment of experimental arthritis by inducing immune tolerance with human adiposederived mesenchymal stem cells. Arthritis Rheum 2009, 60:1006-1019.

62. Zheng ZH, Li XY, Ding J, Jia JF, Zhu P: Allogeneic mesenchymal stem cell and mesenchymal stem cell-differentiated chondrocyte suppress the responses of type II collagen-reactive T cells in rheumatoid arthritis. Rheumatology (Oxford) 2008, 47:22-30.

63. Rafei M, Campeau PM, Aguilar-Mahecha A, Buchanan M, Williams P, Birman E, Yuan S, Young YK, Boivin MN, Forner K, Basik M, Galipeau J: Mesenchymal stromal cells ameliorate experimental autoimmune encephalomyelitis by inhibiting CD4 Th17 T cells in a CC chemokine ligand 2-dependent manner. J Immuno/ 2009, 182:5994-6002.

64. Sun L, Akiyama K, Zhang H, Yamaza T, Hou Y, Zhao S, Xu T, Le A, Shi S: Mesenchymal stem cell transplantation reverses multiorgan dysfunction in systemic lupus erythematosus mice and humans. Stem Cells 2009, 27:1421-1432

65. Lee RH, Seo MJ, Reger RL, Spees JL, Pulin AA, Olson SD, Prockop DJ: Multipotent stromal cells from human marrow home to and promote repair of pancreatic islets and renal glomeruli in diabetic NOD/scid mice. Proc Natl Acad SciU S A 2006, 103:17438-17443.

66. Urban VS, Kiss J, Kovacs J, Gocza E, Vas V, Monostori E, Uher F: Mesenchymal stem cells cooperate with bone marrow cells in therapy of diabetes. Stem Cells 2008, 26:244-253.

67. Fiorina P, Jurewicz M, Augello A, Vergani A, Dada S, La Rosa S, Selig M, Godwin J, Law K, Placidi C, Smith RN, Capella C, Rodig S, Adra CN, Atkinson M, Sayegh $\mathrm{MH}$, Abdi R: Immunomodulatory function of bone marrow-derived mesenchymal stem cells in experimental autoimmune type 1 diabetes. J Immunol 2009, 183:993-1004.

doi:10.1186/scrt2

Cite this article as: Ghannam S, et al: Immunosuppression by mesenchymal stem cells: mechanisms and clinical applications. Stem Cell Research \&

Therapy 2010, 1:2. 